УДК 615.322:581.4:582.632.1

DOI https://doi.org/10.11603/2312-0967.2019.3.10472

\title{
ВИВЧЕННЯ МОРФОЛОГО-АНАТОМІЧНОЇ БУДОВИ БРУНЬОК ВІЛЬХИ КЛЕЙКОЇ ALNUS GLUTINOSA (L.) GAERTN.
}

\author{
О. П. Хворост ${ }^{1}$, Ю. А. Федченкова ${ }^{2}$, К. С. Скребцова ${ }^{1}$, А. І. Попик ${ }^{1}$ \\ Національний фрармацевтичний університет ${ }^{1}$, Харків \\ Ніжинський державний університет імені Миколи Гоголя² \\ khvorost09101960@gmail.com
}

ІНФОРМАЦІЯ

Надійшла до редакції / Received: 15.09.2019

Після доопрацювання / Revised: 20.09.2019

Прийнято до друку / Accepted: 24.09.2019

\section{Ключові слова:}

Alnus glutinosa (L.) Gaertn.;

бруньки;

морфолого-анатомічна будова.

\begin{abstract}
АНОТАЦІЯ
Мета роботи. Дослідити морфолого-анатомічну будову бруньок вільхи клейкої Alnus glutinosa (L.) Gaertn.

Матеріали і методи. За допомогою фрармакопейних методів аналізу дослідили морфологічну та анатомічну будову 5 серій бруньок вільхи клейкої вітчизняних регіонів заготівлі. Морфологічні особливості вивчали не менш ніж на 15 зразках сировини кожної серії. Для дослідження анатомічної будови виготовляли не менш ніж 15 препаратів сировини кожної серії.

Результати й обговорення. Проведені виміри бруньок та криючих брактей (морфометричні показники) дозволили встановити граничні межі довжини та діаметра власне бруньки та довжини і ширини криючих брактей. Складений морфологічний опис бруньок вільхи клейкої з визначенням діагностичних ознак (фрорма, колір, характер поверхні криючих брактей).

Дослідили анатомічну будову бруньок вільхи клейкої. Виділили основні діагностичні риси: фрорма клітин епідерми брактей та пористість їхніх оболонок, типи та топографрія трихом брактей, наявність ефріроолійних залозок.

Висновки. Встановлено особливості морфолого-анатомічної будови 5 серій бруньок вільхи клейкої різних регіонів заготівлі. Визначено морфометричні показники, встановлено граничні межі довжини та діаметра бруньки та криючих брактей. Обрано критерії морфологічного опису та створено морфрологічний опис бруньок вільхи клейкої із визначенням діагностичних ознак. Дослідження анатомічної будови бруньок вільхи клейкої дозволило виділити діагностичні риси сировини. Отриманні результати можуть стати основою для розробки розділів «Ідентифрікація А» та «Ідентифрікація В» проекту монографії на бруньки вільхи клейкої як перспективного виду лікарської рослинної сировини.
\end{abstract}

Вступ. Вільха клейка Alnus glutinosa (L.) Gaertn. - поширена вітчизняна рослина родини березові Betulaceae, переважно зустрічається на берегах водойм, джерел, на заболочених площах. До ДФУ 2.0-2.4 входять монографії «Вільхи супліддя» та «Вільхи клейкої листя» [1]. Листя вільхи клейкої широко застосовують як протизапальний, проти- застудний, антимікробний, послаблювальний засіб [2].

$€$ дані про лісотехнічне значення вільхи клейкої [3], зокрема про вплив заростей вільхи клейкої на ґрунти [4]. Раніше проведено порівняльний аналіз компонентного складу фенольних сполук та сполук, що переганяються 3 водяною парою в бруньках та

ISSN 2312-0967. Pharmaceutical review. 2019. № 3 


\section{Pharmaceutical botany}

листі вільхи клейкої, що заготовлено в одному і тому ж місці [5, 6]. Широко вивчають типи ектомікориз вільхи клейкої [7]. Крім того, вільха клейка є джерелом цінної деревини [8], її пагони застосовують як об'єкт для біотехнологічних дослідів [9].

Народна медицина пропонує настій листя та настойку бруньок вільхи клейкої включати до протипухлинних комплексних засобів, особливо при ракових ураженнях підшлункової залози, стравоходу та прямої кишки. Також є дані про використання цих видів сировини для ефективних компресів та сухих ван для ніг, що зменшують втому, попрілості тощо.

Мета роботи - дослідити морфолого-анатомічну будову бруньок вільхи клейкої.

Матеріали і методи. Сировину - бруньки вільхи клейкої заготовили в березні-квітні 2017 р. у різних регіонах України: серія 1-Вінницька область, Козятинський р-н, с. Глухівці; серія 2 - Івано-Франківська область, Яремченський р-н, смт Яремче; серія 3 - Харківська область, Харківський р-н, с. Черкаські Тишки; серія 4 Львівська область, Жидачівський р-н, с. Жирова; серія 5 - Чернігівська область, Чернігівський р-н, с. Новоселівка. Дослідження проводили відповідно до вимог ДФУ 2.0 [1]. Морфологічні особливості вивчали за допомогою лупи х2, х10, стереомікроскопа «МБС-10» (Росія) (16x, 32x) за загальноприйнятими методиками [10], вимірювання проводили не менш ніж на 15 зразках сировини кожної серії. Анатомічну будови досліджували за допомогою мікроскопа «Granum» (Austria) ( 40x, 100x, 400x). Виготовляли не менш ніж 15 препаратів сировини кожної серії. Результати фріксували за допомогою цифррової фротокамери «Sony DSC-W80» 3 наступною обробкою в програмі Adobe Photoshop CS3 [11].

Результати й обговорення. Морфометричні показники серій бруньок та криючих брактей наведено у таблиці. Числові параметри сировини різних серій варіювали в межах: довжина бруньки - 8,0 - 12,0 мм, ії діаметр - 2,4 - 3,5 мм.

Бруньки видовжено-конічні, загострені або притуплені, часто клейкі

Криючі брактеї коричнювато-фріолетового кольору, шкірясті з ледь зморшкуватою поверхнею. Ледь війчасті брактеї розміщені щільно, стисло; завдовжки 7 - 10 мм, завширшки 1,5 - 3,0 мм.

Вивчали морфрологічні особливості бруньок вільхи клейкої. Зовнішній вигляд бруньок наведено на рисунку 1, А, поздовжній зріз бруньки - на рисунку 1, Б, поперечний зріз - на рисунку 1, В.

На поздовжньому зрізі, крім зовнішніх покривних, помітні асимілюючі брактеї з щільним опушенням білими волосками.

На поперечному зрізі помітні хвилясті асимілюючі брактеї з опушенням, аналогічним опушенню брактей на поздовжньому зрізі.

Епідерма брактеї бруньки на препараті з поверхні (рис. 2, А) представлена прямо-, тонкостінними дріб-

\section{Таблиця}

Числові параметри бруньок вільхи клейкої

\begin{tabular}{|c|c|c|c|c|}
\hline \multirow{2}{*}{ № серії } & \multicolumn{2}{|c|}{ Брунька, мм } & \multicolumn{2}{c|}{ Криюча брактея, мм } \\
\cline { 2 - 5 } & довжина & діаметр & довжина & ширина \\
\hline 1 & 8,0 & 2,4 & 7,0 & 2,5 \\
\hline 2 & 9,2 & 2,6 & 8,0 & 3,0 \\
\hline 3 & 12,0 & 3,5 & 10,0 & 1,5 \\
\hline 4 & 10,0 & 2,8 & 8,0 & 2,0 \\
\hline
\end{tabular}

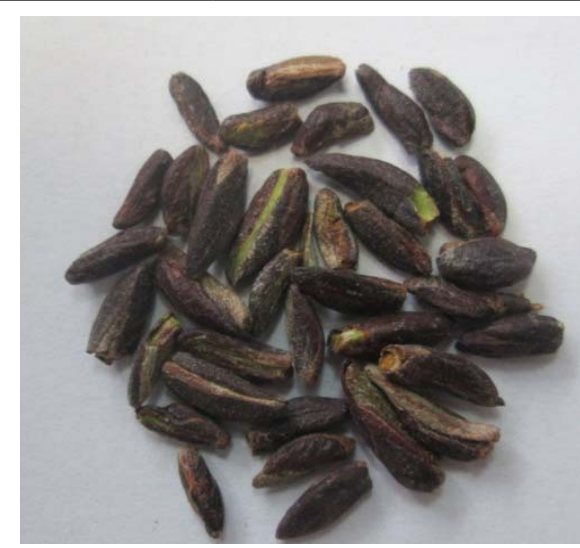

A

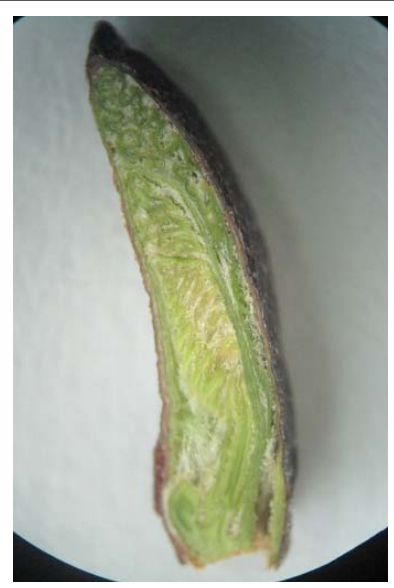

Б

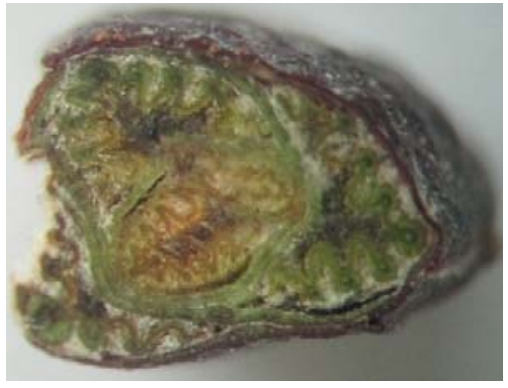

B

Рис. 1. Морфологічні особливості бруньок вільхи клейкої: А - зовнішній вигляд, Б - поздовжній зріз бруньки, В - поперечний зріз бруньки.

ISSN 2312-0967. Фармацевтичний часопис. 2019. № 3 
ними клітинами, спостерігається значна кількість ефіроолійних залозок із вмістом коричневого кольору.

На рисунку 2, Б наведено діагностичну рису анатомічної будови бруньок - пористість клітинних оболонок епідермальних клітин брактеї. На рисунку 2, В наведено опушення простими одноклітинними волосками різної довжини, різного ступеня звивистості,

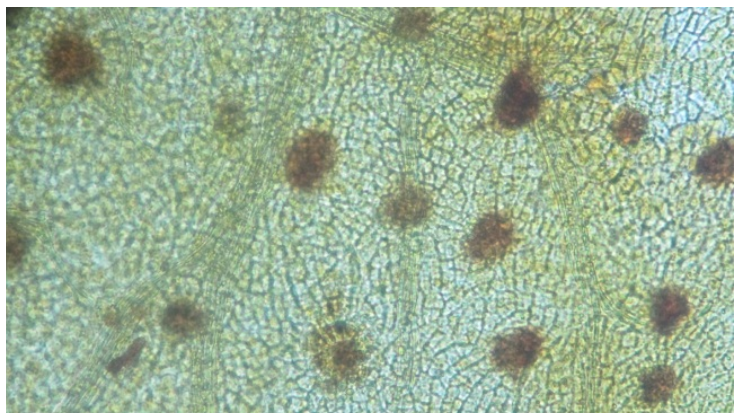

A

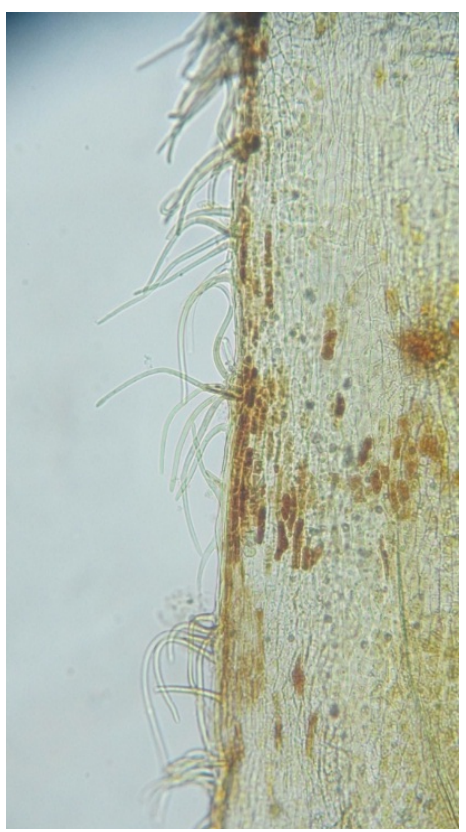

B

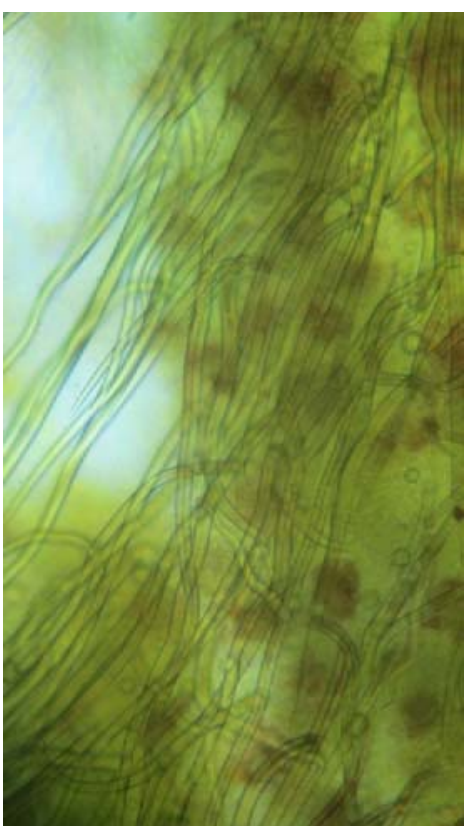

що розміщені нерівномірно, з утворенням пучків. Це надає краю брактеї певну війчатість.

На рисунку 2, Г і 2, Д наведено варіанти щільного опушення брактеї. Опушення представлено переважно простими звивистими волосками з потовщеними оболонками та дуже тонкими ледь помітними ниткоподібними порожнинами складових клітин.
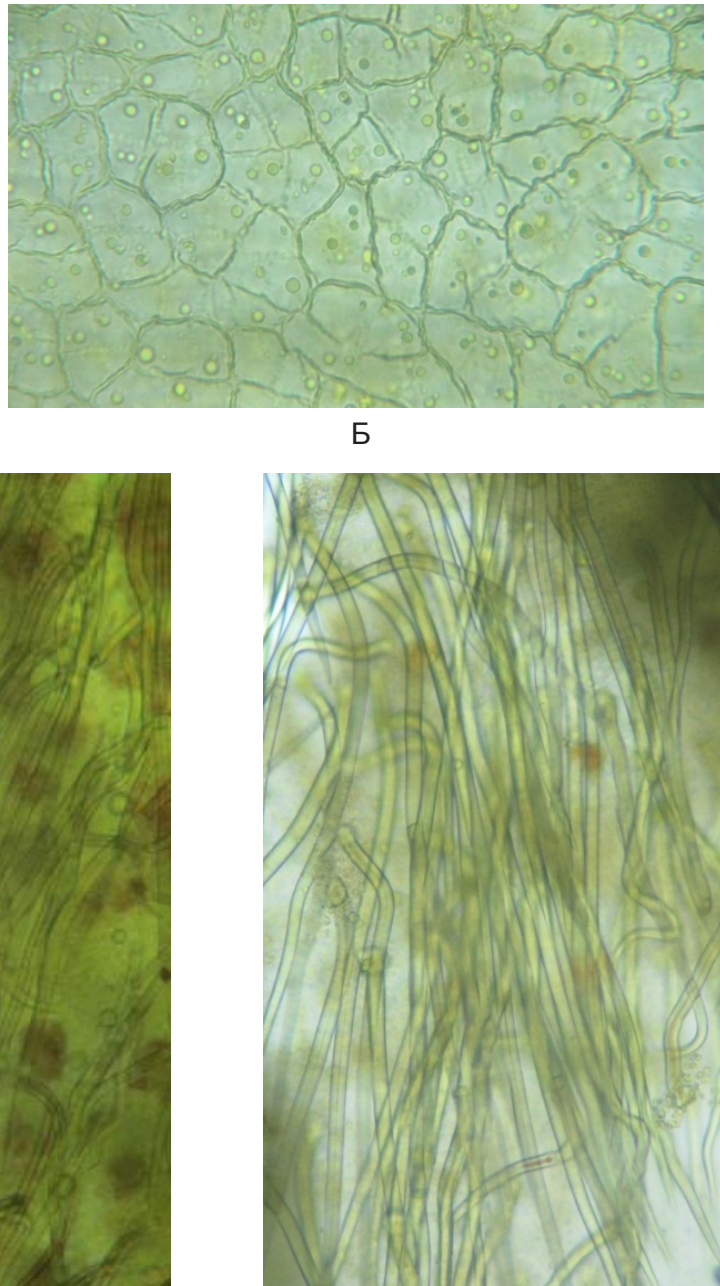

Д

Рис. 2. Діагностичні особливості анатомічної будови бруньок вільхи клейкої: А - залозки епідерми асимілюючої брактеї; Б - пористість клітин епідерми асимілюючої брактеї, В - війчатість опушення краю криючої брактеї, Г-Д - варіанти трихом епідерми брактей.

Висновки. 1. Встановлено особливості морфолого-анатомічної будови 5 серій бруньок вільхи клейкої різних регіонів заготівлі.

2. Визначено морфометричні показники, встановлено граничні межі довжини та діаметра бруньки та криючих брактей.

3. Обрано критерії морфологічного опису та створено морфологічний опис бруньок вільхи клейкої із визначенням діагностичних ознак (форма, колір, характер поверхні криючих брактей).

4. Дослідження анатомічної будови бруньок вільхи клейкої дозволило виділити діагностичні риси: типи та топографрія трихом брактей, наявність залозок, фрорма клітин епідерми та пористість їх оболонок.

5. Одержані результати можуть стати основою для розробки розділів «Ідентифікація А» та «Ідентифрікація В» проекту монографрії на бруньки вільхи клейкої як перспективного виду лікарської рослинної сировини.

Конфлікт інтересів: відсутній.

Conflicts of interest: authors have no conflict of interest to declare.

ISSN 2312-0967. Pharmaceutical review. 2019. № 3 
Фармацевтична ботаніка

Pharmaceutical botany

\title{
A STUDY OF THE MORPHOLOGICAL-ANATOMIC STRUCTURE OF THE BUDS OF BLACK ALDER ALNUS GLUTINOSA (L.) GAERTN.
}

\author{
O. P. Khvorost ${ }^{1}$, Yu. A. Fedchenkova ${ }^{2}$, K. S. Skrebtsova ${ }^{1}$, A. I. Popik ${ }^{1}$ \\ National University of Pharmacy ${ }^{1}$, Kharkiv \\ Nizhyn Mykola Hohol State University² \\ khvorost09101960@gmail.com
}

The aim of the work. Research of the morphological and anatomical structure of black alder buds.

Materials and Methods. The pharmacopoeial methods of analysis investigated the morphological and anatomical structure of 5 series of buds of black alder of ordinary domestic harvest. Morphological features were studied at no less than 15 samples of raw materials of each series. The anatomical structure was studied at no less than 15 samples of raw materials of each series.

Results and Discussion. The measurements of the buds and covering margins (morphometric parameters) made it possible to set the boundaries of the length and diameter of the bud and the length and width of the covering margins. The morphological description of black alder buds with the definition of diagnostic features is made (the size, shape and color of the buds and the covering bracts).

The anatomical structure of the black alder buds was investigated. The main diagnostic features were identified: the shape of the cells of the epidermis of the bracts and the porosity of their shells, the types and topography of the thrichoms of the bracts, the presence of essential oil glands.

Conclusions. Features of the morphological and anatomical structure of 5 series of adhesive alder buds of various harvesting regions have been established. Morphometric indices were determined, limits for the length and diameter of the buds and ophthalmic bracts were established. The criteria for the morphological description were selected and a morphological description of the sticky alder buds was created with the definition of diagnostic signs. The study of the anatomical structure of sticky alder buds made it possible to identify the diagnostic features of raw materials. The obtained results can become the basis for the development of the sections "Identification A" and "Identification B" of the draft monograph on the sticky alder buds as a promising type of medicinal plant material.

Key words: Alnus glutinosa (L.) Gaertn.; buds; morphological and anatomical structure.

\section{ИЗУЧЕНИЕ МОРФОЛОГО-АНАТОМИЧЕСКОГО СТРОЕНИЯ ПОЧЕК ОЛЬХИ КЛЕЙКОЙ ALNUS GLUTINOSA (L.) GAERTN.}

\author{
О. П. Хворост ${ }^{1}$, Ю. А. Федченкова ${ }^{2}$, Е. С. Скребцова ${ }^{1}$, А. И. Попик ${ }^{1}$ \\ Национальный фрармацевтический университет ${ }^{1}$, Харьков \\ Ниженский государственный университет имени Николая Гоголя² \\ khvorost09101960@gmail.com
}

Цель работы. Исследовать морфолого-анатомическое строение почек ольхи клейкой Alnus glutinosa (L.) Gaertn. Материалы и методы. С помощью фрармакопейных методов анализа исследовали морсологическое и анатомическое строение 5 серий почек ольхи клейкой отечественных регионов заготовки. Морфологические особенности изучали не менее чем на 15 образцах сырья каждой серии. Для исследования анатомического строения изготавливали не менее 15 препаратов сырья каждой серии.

Результаты и обсуждение. Проведенные измерения почек и кроющих брактей (моророметрические показатели) позволили установить предельные границы длины и диаметра собственно почки, а также длины и ширины кроющих брактей. Составлено морфологическое описание почек ольхи клейкой с определением диагностических признаков (форма, цвет, характер поверхности кроющих брактей).

Исследовали анатомическое строение почек ольхи клейкой. Выделили основные диагностические особенности: фрорма клеток эпидермы брактей и пористость их оболочек, типы и топографрия трихом брактей, наличие эфиромасличных железок.

Выводы. Установлены особенности морфолого-анатомического строения 5 серий почек ольхи клейкой различных регионов заготовки. Определены морфометрические показатели, установлены предельные границы длины и диаметра почки и кроющих брактей. Выбраны критерии морфологического описания и создано морфологическое описание почек ольхи клейкой с определением диагностических признаков. Исследование анатомического строения почек ольхи клейкой позволило выделить диагностические особенности сырья. Полученные результаты могут стать основой для разработки разделов «Идентификация А» и «Идентификация

ISSN 2312-0967. Фармацевтичний часопис. 2019. № 3 
В» проекта монографии на почки ольхи клейкой как перспективного вида лекарственного растительного сырья.

Ключевые слова: Alnus glutinosa (L.) Gaertn.; почки; морфолого-анатомическое строение.

\section{Список літератури}

1. Державна Фармакопея України: в 3 т. / ДП «Український науковий срармакопейний центр якості лікарських засобів». - 2-ге вид. - Х. : ДП «Український науковий фрармакопейний центр якості лікарських засобів», 2015. - Т. 1. - 1128 с.

2. Федченкова Ю. А. Антимикробная активность субстанций, полученных из сырья растений семейства Березовые / Ю. А. Федченкова, Е. М. Савинова // Аннали Мечниковського института. - 2016. - № 4. - C. $84-87$.

3. A review of the characteristics of black alder (Alnus glutinosa (L.) Gaertn.) and their implications for silvicultural practices / H. Claessens, A. Oosterbaan, P. Savill [et al.] // Forestry: An International Journal of Forest Research. - 2010. - Vol. 83, Iss. 2, - P. 163-175. Access mode : https://doi.org/10.1093/forestry/cpp038

4. The impact of alders (Alnus spp.) on the physico-chemical properties of technosols on a lignite combustion waste disposal site / M. Pietrzykowski, B. Woś, M. Pająk [et al.]. // Ecological Engineering. - 2018. - Vol. 120. P. 180-186

5. Федченкова Ю. А. Дослідження деяких френольних сполук бруньок та листя вільхи клейкої. / Ю.А.Федченкова, О. П. Хворост // Збірник наукових праць співробітників НМАПО ім. П. Л. Шупика. - 2015. Вип. 24, кн. 5. - С. 243-246.

\section{References}

1. State Pharmacopoeia of Ukraine: in 3 volumes. [Державна Фармакопея України: в 3 т.] Kharkiv: State Enterprise "Ukrainian Scientific Pharmacopoeial Center for Medicinal Products Quality; 2015. Ukrainian.

2. Fedchenkova YuA, Savinova EM. Antimicrobial activity of substances obtained from raw materials of plants of the Birch family. Annaly Mechnikov Inst. 2016;4: 84-7. Russian.

3. Claessens H, Oosterbaan A, Savill P, Rondeux J. Forestry. A review of the characteristics of black alder (Alnus glutinosa (L.) Gaertn.) and their implications for silvicultural practices. An International Journal of Forest Research. 2010;83: 2, 163-175. Available from: https:// doi.org/10.1093/forestry/cpp038

4. Pietrzykowski M, Woś B, Pająk M, Wanic T, Wojciech Krzaklewski W, Chodak M. The impact of alders (Alnus spp.) on the physico-chemical properties of technosols on a lignite combustion waste disposal site. Ecological Engineering. 2018; 120: 180-186.

5. Fedchenkova YuA, Khvorost OP. Investigation of some phenolic compounds of kidneys and alder leaves of gummy. Collection of scientific works of NMAPE employees. P. L. Shupik; 2015;24(5): 243-246. Ukrainian.
6. Хворост О. П. Сравнительный анализ состава соединений, перегоняющихся с водяным паром, почек и листьев Alnus glutinosa (L.) Gaertn. / О. П. Хворост, Ю. А. Федченкова, Г. И. Биленко // «Рецепт» УП «Просрессиональные издания» (Беларусь). - 2013. - № 5. - С. 75 - 80.

7. Pritsch K. Morphological and anatomical characterisation of black alder Alnus glutinosa (L.) Gaertn. I K. Pritsch, C. Munch, F. Buscot // J. Ectomycorrhizas Mycorrhiza. - 1997. - Vol. 7, Iss. 4. - P. 201-216.

8. Bajji M. Adventitious shoot regeneration from in vitro juvenile explants of black alder (Alnus glutinosa [L.] Gaertn.) / M. Bajji, Ph. Druart, C. Thunissen // J. Biotechnology, Agronomy, Society and Environment. 2013. - No. 17(1) - P. 12-19.

9. Anatomical study of short-term thermo-mechanically densified alder wood veneer with low moisture content / P. Bekhta, M. Memonova, J. Sedliacik [et al.] // Eur. J. Wood Prod. - 2016. - No 74(5) - P. 643-652. DOI 10.1007/s00107-016-1033-2

10. Справочник по ботанической микротехнике. Основы и методы / [Р. П. Барыкина, Т. Д. Веселова, А. Г. Девятова и др.]. - М. : Изд-во МГУ, 2004. - 312 с.

11. Атлас по анатомии растений (растительная клетка, ткани, органы) : учеб. пособие для высш. учеб. завед. / [А. Г. Сербин, Л. С. Картмазова, В. П. Руденко и др.]. - Харьков : Колорит, 2006. - 86 с.

6. Khvorost OP., Fedchenkova YuA., Bilenko GI. Comparative analysis of the composition of compounds distilled with water vapor, buds and leaves of Alnus glutinosa (L.) Gaertn. "Recipe" UE "Professional publications"; 2013;5: 75-80. Russian.

7. Pritsch K., Munch J. C., Buscot F. Morphological and anatomical characterisation of black alder Alnus glutinosa (L.) Gaertn. Ectomycorrhizas. Mycorrhiza. 1997;7:4: 201-16.

8. Bajji M., Druart Ph., Thunissen C. Adventitious shoot regeneration from in vitro juvenile explants of black alder (Alnus glutinosa [L.] Gaertn.) Biotechnology, Agronomy, Society and Environment. 2013;17(1): 12-9.

9. Bekhta P, Memonova M, Sedliacik J, Novak I. Anatomical study of short-term thermo-mechanically densified alder wood veneer with low moisture content. Eur J Wood Prod. 2016;74(5): 643-52. DOI 10.1007/s00107016-1033-2

10. Barykina RP., Veselova TD., Devyatova AG. et al. Handbook of Botanical Microtechnology. Basics and methods. [Справочник по ботанической микротехнике. Основы и методы] 2004; Moscow: Publishing House of Moscow State University. Russian

ISSN 2312-0967. Pharmaceutical review. 2019. № 3 
11. Serbin AG, Kartamazova LS, Rudenko VP. Atlas of plant anatomy (plant cell, tissues, organs): textbook. tool. for university students. teach. Institutions. [Атлас 3 анатомії рослин (рослинна клітина, тканини, органи): навч. посіб. для студентів вищ. навч. закладів] 2006; Kharkiv: Koloryt. Ukrainian.

\section{Відомості про авторів:}

Хворост О. П. - д. фрармац. н., професор, професор кафедри хімії природних сполук і нутриціології, Національний фрармацевтичний університет, Харків, Україна. E-mail : khvorost09101960@gmail.com, ORCID 0000-0002-9534-1507

Федченкова Ю. А. - Д. фрармац. н., професор кафедри хімії та фрармації, Ніжинський державний університет імені Миколи Гоголя, Ніжин, Україна. E-mail: fja_fja@ukr.net, ORCID 0000-0003-1240-3053

Скребцова К. С. - канд. фрармац. н., асистент кафедри хімії природних сполук і нутриціології, Національний фрармацевтичний університет, Харків, Україна. E-mail: musienko.pharm@gmail.com, ORCID 0000-0002-7421-8761

Попик А. І. - канд. фрармац. Н., асистент кафредри хімії природних сполук і нутриціології, Національний фрармацевтичний університет, Харків, Україна. E-mail: aicnc2016@gmail.com, ORCID 0000-0003-1422-3662

\section{Information about the authors:}

Khvorost O. P. - DS (Pharmacy), Professor, Professor of the Chemistry of Natural Compounds and Nutricion Department, National University of Pharmacy, Kharkiv, Ukraine. E-mail: khvorost09101960@gmail.com, ORCID 0000-0002-9534-1507 Fedchenkova Yu. A. - DS (Pharmacy), Professor of the Chemistry and Pharmacy Department, Nizhyn Mykola Hohol State University, Nizhyn, Ukraine. E-mail: fja_fja@ukr.net, ORCID 0000-0003-1240-3053

Skrebtsova K. S. - PhD (Pharmacy), assistant of the Chemistry of Natural Compounds and Nutricion Department, National University of Pharmacy, Kharkiv, Ukraine. E-mail: musienko.pharm@gmail.com, ORCID 0000-0002-7421-8761

Popik A. I. - PhD (Pharmacy), assistant of the Chemistry of Natural Compounds and Nutricion Department, National University of Pharmacy, Kharkiv, Ukraine. E-mail: aicnc2016@gmail.com, ORCID 0000-0003-1422-3662 